\title{
DIE VERBAND TUSSEN WERKNEMERSTATUS EN WERK- HOUDINGS IN 'N WINKELGROEP
}

\author{
FG PRINSLOO \\ AL BARNARD \\ Departement Bedryf-en Personeelsielkunde \\ Potchefstroomse Universiteit vir $\mathrm{CHO}$
}

\begin{abstract}
The relation between employment status and work attitudes in a retail group. Employment status refers to the type of employment contract that may be concluded between an employer and an employee. It rests upon a continuum, varying from a permanent full-time appointment to a temporary appointment for a certain task or period. More and more organisations maintain a smaller core group of permanent full-time employees, which is supplemented by temporary or part-time employees. In this research the job satisfaction of full-ime and part-time workers in a retail group is compared. The part-time group differed significantly from the full-time group regarding one facet of job satisfaction namely a lower level of satisfaction with supervision.
\end{abstract}

\section{OPSOMMING}

Werknemerstatus het betrekking op die tipe dienskontrak wat tussen ' $n$ werkgewer en werknemer gesluit word. Dit berus op ' $n$ kontinuum wat wissel vanaf ' $n$ permanent-voltydse aanstelling tot ' $n$ tydelike aanstelling vir ' $n$ bepaalde taak of tydperk. Meer en meer organisasies handhaaf' $n$ kleiner kerngroep van permanent-voltydse werknemers, wat aangevul word met tydelike of deeltydse werknemers. In hierdie navorsing word die werktevredenheid van voltydse en deeltydse werknemers in ' $n$ winkelgroep vergelyk. Die deeltydse groep het beduidend van die voltydse groep verskil ten opsigte van een faset van werktevredenheid, naamlik ' $n$ laer vlak van tevredenheid met toesighouding.

Dit is so dat organisasies wêreldwyd gedurende die afgelope aantal dekades in hul menslike hulpbronvoorsiening meer en meer die klem begin plaas het op 'n kleiner korps van permanente, voltydse kernpersoneel, wat aangevul word met deeltydse of tydelike werkers na gelang van behoefte. Hierdie feit kom telkens na vore wanneer die literatuur oor deeltydse en tydelike arbeid geraadpleeg word (Casey, 1988; Feldman \& Doerpinghaus \& Turnley, 1995; Houseman, 1995; Lewis \& Schuman, 1988; Robinson, 1993; Rotchford \& Roberts, 1982). Deeltydse en tydelike werkers speel dikwels 'n uiters belangrike rol om organisasies te help om hul doelwitte te bereik.

In die literatuur word twee hoofkategorieë van werkverskaffing aangetref, naamlik permanente, voltydse of tradisonele werk aan die een kant, en atipiese vorms van werkverskaffing wat hiervan afwyk (Dederichs en Köhler, 1993; Levy, 1995; McRae, 1989; Sander, 1989; Syrett, 1983). Atipiese vorms van werk wat dikwels aangetref word, is verminderde weeklikse werkure soos 'n vier-dag werkweek, vaste termyn werk, skiktyd ("flexible working hours"), werksdeling ("job-sharing"), aand- of naweekwerk, en deeltydse of tydelike werk (Dederichs \& Köhler, 1993:18; Moberley, 1987:689; Sander, 1989:322). Die algemeenste vorms van atipiese of nie-tradisionele werk, is deeltydse en tydelike werk.

Volgens Houseman (1995:19) is daar geen standaard definisie van deeltydse werk nie: "Definitions vary greatly across countries, and sometimes across statistical publications within countries". Dederichs en Köhler (1993:19) definieer deeltydse werk as "all working-time arrangements with a contractual working time below the full-time level ... irrespective of how long the normal working hours actually are". Tensy daar anders ooreengekom word, is voltydse sowel as deeltydse werknemers, permanente werknemers. Die tydelik-deeltydse werknemer kan beskou word as 'n kontrakwerker. Soos uit dic benaming afgelei kan word, word die werknemer nie permanent aangestel nie.

'n Tydelike werker is 'n werknemer wat tydelik aangestel word om teen vergoeding 'n bepaalde taak by 'n werkgewer te verrig en te voltooi, of andersins vir 'n vooraf bepaalde tydperk aangestel word om 'n bepaalde taak of take by 'n werkgewer te verrig, waarna die indiensnemingskontrak verval. Die tydelike werknemer kan direk deur die betrokke werkgewer self in diens geneem en vergoed word. Die indiensneming kan ook geskied deur die bemiddeling van 'n derde persoon of instansie, wat die werknemer vergoed, terwyl die derde persoon of instansie vergoeding vanaf die werkgewer bekom soos vooraf ooreengekom (Prinsloo, 1997). Voorbeelde is konsultante, halfgeskoolde en geskoolde arbeid in die boubedryf, los ("casual") werknemers, seisoenale werkers, vaste-termyn kontrakwerkers, werkers wat 'n bepaalde taak moet uitvoer (kontrakwerkers), werkers met opleidingskontrakte, tydelike werkverskaffingsdienste ("temping") (Casey, 1988). 'n Tydelike werknemer word onderskei van 'n tydelikdeeltydse werknemer deurdat laasgenoemde deeltyds werk, bo en behalwe vir die feit dat die aanstelling tydelik is.

Die deeltydse arbeidsektor verteenwoordig 'n groot en groeiende deel van die werksmag in Europa, Japan en die VSA (Houseman, 1995). Die deeltydse werksmag in die V.S.A. (werknemers wat minder as 35 uur per week werk) het vanaf $12 \%$ in 1957 gegroei tot meer as $20 \%$ in 1992, wat meebring dat daar meer as 20 miljoen deeltydse werkers in die V.S.A. is (Feldman \& Doerpinghaus, 1992a). In baie diensorganisasies, soos die kleinhandel en "fast-food"-restaurante, maak deeltydse werkers meer as die helfte van die werkerskorps uit. In die Verenigde Koninkryk en Swede is die persentasie deeltydse werkers besig om te groei tot ' $n$ kwart van die totale arbeidsmag (Robinson, 1993).

Wat die groei in die tydelike werksmag in die VSA (kontrakwerkers of werkers wat deur arbeidmakelaars oftewel tydelike-werkverskaffingsdienste, aan organisasies voorsien word) betref, som Feldman et al. (1995), met verwysing na verskeie bronne, die situasie soos volg op:

"Today, the number of temporary employees in the U.S. is 1.5 million, having tripled over the last decade. Temporary employment is now a 20 billion dollar a year business in this country, and the number of temporary help services in the U.S. has increased $1,000 \%$ over the past ten years". 
Hierdie situasie word ook in Europa aangetref. In Engeland, ltalië en Switserland groei die aantal arbeidmakelaars met 10 to 12 persent per jaar (Backer, 1996)

Volgens Moberley (1987) gaan die wêreldwye groei in deeltydse en tydelike arbeid gepaard met 'n toenemende verkleining van die industriele sektor tecnoor 'n groei van die dienstesektor. Die dienstesektor is egter gebonde aan wisselende marktoestandc. Sedert die tagtigerjare moes organisasies toenemend poog om hul arbeidskoste te behecr deur die grootte van hul arbeidsmag vinnig aan te pas na gelang van wisselende marktoestande

Besighede kan nie langer bekostig om groot arbeiderpoele, met werknemers wat elke spesialisvaardigheid verteenwoordig, op 'n permanent-voltydse basis te onderhou nie. Terselfdertyd moet hul werknemers vermeerder kan word in verhouding tot die vraag na hul produkte of dienste, indien dit vereis word. Organisasies wil nie bestellings wegwys omdat hulle nie genoeg werknemers het nie, of dit verloor omrede hulle nie aan vinnige lewering kan voldoen nie, Tydelike personeel bring geen ekstra koste mee nie. 'n Ekonomiese afplatting beteken nie noodwendig personeelafdankings nie, maar slegs dat ' $n$ periode waartydens van tydelike personeel gebruik gemaak is, tot ' $n$ einde gekom het. Organisasies word bevoordeel deurdat tydelike werknemers aangestel word, teenoor die trauma en finansièle verliese wat gepaardgaan met rasionalisasie, sodra ekonomiese afplatting intree na ' $n$ groeifase (Casey, 1988; Lewis \& Schuman, 1988). Baie organisasies maak daarom toenemend gebruik van deeltydse en tydelike werknemers, soos seisoenale werkers, vaste-termyn kontrakwerkers (aanstelling vir ' $n$ bepaalde periode) en kontrakwerkers met ' $n$ aanstelling vir ' $n$ bepaalde taak, of ' $n$ onbepaalde penode (Casey, 1988)

Volgens Klerck (1991) word meer en meer werkers in SuidAfrika in diens geneem as deeltvdse en tydelike werknemers. In hierdie verband verwys Volodia (1991) na die groot persentasie tydelike werknemers wat deel uitmaak van die totale werkerkorps in die kleinhandel. Groot getalle onwettige arbeidmakelaars - tussen 3000 en 5000 - is in Suid-Afrika werksaam, terwyl amptelike syfers toon dat daar slegs ongeveer 800 geregistreerde arbeidmakelaars werksaam is (Backer, 1996). Arbeidmakelaars voorsien werkers met die nodige opleiding en vaardighede vir ' $\mathrm{n}$ halwe dag, of ' $\mathrm{n}$ jaar of langer' aan organisasies na gelang van behoefte. In die VSA staan hierdie praktyk bekend as "temping", en word die verskynsel van die professionele of hoévlak tydelike werknemer beleet. Dit is professionele persone wat die sekuriteit van ' $n$ voltydse, permanente betrekking vernul het vir ' $n$ "vryer" en meer "romantiese" lewenstyl. Lewis en Schuman (1988) som hierdie houding soos volg op: "It is okay to make your career fit around your life, rather than your life around your career".

Navorsing oor die houdings en gedrag van deeltydse en tydelike werkers is min en gefragmenteerd. In die vroeë tagtigerjar: het Rotchford en Roberts (1982) opgemerk dat deeltydse werkers as die "missing persons" in organisasienavorsing beskou kan word. Navorsing is tot dusver hoofsaaklik ten opsigte van twee temas gedoen, naamlik die verskille tussen die werkverwante houdings van voltydse en deeltydse werkers, en tweedens die invloed van demografiese veranderlikes op individue se reaksies op deeltydse werk (Hall \& Gordon, 1973; Soumerai \& Avom, 1983). Gedurende die sewentiger- en tagtigerjare is navorsing hoofsaaklik toegespits op die verskille tussen voltydse en deeltydse werkers.

In die negentigerjare volg ' $n$ herkonseptualisering van navorsing aangaande deeltydse werkers. (Eberhardt \& Moser. 1995; Feldman \& Doerpinghaus, 1992a; 1992b; Nkomo \& Fields, 1994), na aanleiding van Feldman (1990) se standpunt dat navorsers eerder die invloed van die verskillende tipes werkskontrakte, wat afwyk van tradisionele permanente, voltydse werk, byvoorbeeld permanent-deeltydse of tydelike werk, op individue behoort te ondersoek, as om te fokus op die verskille tussen voltydse en deeltydse werkers. Die waar- genome verskille in reaksies op deeltydse werk by verskillende demografiese groepe (byvoorbeeld afgetrede persone of voltydse studente) kan moontlik toegeskryf word aan dic feit dat die tipes deeltydse werk nie dieselfde aantrekkingskrag vir alle potensiële deeltydse werkers het nie. 'n Persoon wat vrywillig deeltyds wil werk, verkies ' $n$ werk wat pas by sy/haar persoonlike omstandighede. Gevolglik ontstaan verskillende groepe deeltydse werkers met verskillende demografiese profiele, wat verband hou met werksomstandighede, soos seisoenale werk.

Uit die beskikbare navorsingsgetuienis kan daar nie konsekwente verskille aangetoon word wat betref werkverwante houdings van voltydse en deeltydse werkers ne. Dit is waarskynlik daaraan toe te skryf dat omstandighede by elke studie telkens verskil ten opsigte van beroepstipe, organisasietipe, werkomstandighede, organisasiekultuur en redes waarom deeltyds gewerk word (vrywillig of nie-vrywillig). Daarby verskil die doelstellings van navorsers, en word verskillende navorsingsontwerpe, steekproefsamestellings en meetinstrumente gebruik. In hierdie verband kom Jackofsky en Peters (1987) na 'n deurskouing van die literatuur tot die gevolgtrekking dat vergelykings van voltydse en deeltydse werkers se reaksies op werk teenstrydige resultate opgelewer het.

Die veranderlikes wat tot dusver in navorsing oor die verskille tussen voltydse en deeltydse werkers gemeet is, kan soos volg opgesom word:

- werktevredenheid (Darden, McKee \& Hampton, 1993: Eberhardt \& Moser, 1995; Eberhardt \& Shani, 1984; Feldman \& Doerpinghaus, 1992a; 1992b; Fields \& Thacker, 1991; Hom, 1979; Jackofsky \& Peters, 1987; Logan, O'Reilly \& Roberts, 1973; Miller \& Terborg, 1979; Wetzel, Soloshy \& Gallagher, 1990; Wotruba, 1990)

- organisasie-eienskappe (Eberhardt \& Shani, 1984)

- werkverwagtinge (Feldman \& Doerpinghaus, 1992a; 1992b; Shocky \& Mueller, 1994)

- voorspelbaarheid van personeelomset (Peters, Jackofsky \& Salter, 1981)

- deeltydse werk saam met ' $n$ voltydse werk en omgekeerd (Wotruba, 1990)

- werkbetrokkenheid (Darden et al., 1993; Wakefield, Curry, Mueller \& Price, 1987)

- deelnemende besluitneming (Darden et al., 1993; Wakefield et al., 1987)

- organisasieverbintenis (Wakefield et al., 1987)

- werkprestasie (Darderi et al., 1993; Wakefield et al., 1987)

- gewone werkure en ongewone werkure Jackofsky \& Peters, 1987)

- keuse ten opsigte van werkskedule (Lee \& Johnson, 1991)

In die literatuur aangaande die verskille tussen voltydse en deeltydse werkers word die begrip "werknemerstatus" ("fulltime/part-time employment status") dikwels aangetref. Dit hou verband met die aanstelling van ' $n$ werknemer deur ' $n$ werkgewer deur middel van 'n dienskontrak. Hierdie kontrak spesifiseer die termyn waarvolgens die werknemer by die werkgewer in diens sal wees. Werknemerstatus het ook betrekking op die hoeveelheid werkure wat die werknemer vir die werkgewer sal werk - "voltyds", indien dit normale werkure behels, en "deeltyds" indien dit minder as die normale werkure behels. Werknemerstatus berus op ' $n$ kontinuum wat wissel vanaf ' $n$ aanstelling op ' $n$ permanent-voltydse of permanent-deeltydse grondslag, tot ' $n$ aanstelling op ' $n$ tydelike basis vir ' $n$ bepaalde taak of tydperk op ' $n$ voltydse of deeltydse basis wat ' $n$ paar uur of langer, selfs jare, kan duur. Werknemerstatus het wat hierdie studie en die bovermelde navorsing betref, nie betrekking op die status van die werknemer in die organisasiehiërargie, dit wil sê rang of posvlak nie.

Die algemene doel van hierdie ondersoek is om te bepaal of daar ' $n$ verband bestaan tussen werknemerstatus en werkhoudings deur middel van ' $n$ werkerpopulasiesteekproef soos dit tipies in die kleinhandel in Suid-Afrikaanse omstandighede aangetref word. In die Suid-Afrikaanse kleinhandel word 
tipies die situasie van die permanente los werker ("permanent casual worker") aangetref (Levy, 1995). Dit is die tydelikedeeltydse werker waarna reeds verwys is, wat deeltyds vir 'n werkgewer werk en nie permanent aangestel word nie. Inderwaarheid word hierdie tydelik-deeltydse aanstelling op 'n permanente basis voortgesit wat jare kan duur, en vorm hierdie werkers prakties gesproke deel van die permanente werknemerskorps van die organisasie. Hierdie werkers werk gereeld oor naweke, of gedurende aandskofte. In die voorgestelde nuwe Wet op Basiese Diensvoorwaardes (Groenskrif) word die benaming "casual worker" as 'n "misnomer" beskryf (Levy, 1996). Hierdie tipe werkers sal ingevolge die nuwe wetgewing waarskynlik in die toekoms as deeltydse werkers aangestel moet word. Aangesien die steekproef wat vir hierdie studie gebruik is, hierdie tipiese permanente los werkers, wat vir alle praktiese doeleindes as permanente deeltydse werkers beskou kan word, insluit, sal daar voorts na hulle verwys word as "deeltydse werkers".

Die spesifieke doelstelling van hierdie ondersoek is om te bepaal of daar verskille bestaan tussen permanent-voltydse en deeltydse werknemers ten opsigte van die volgende veranderlikes wat werkhouding weerspieël:

- werktevredenheid as geheel, en ten opsigte van die volgende spesifieke werksfasette:

- tevredenheid met besoldiging

- tevredenheid met werksekuriteit

- tevredenheid met sosiale aspekte

- tevredenheid met toesighouding

- tevredenheid met groei- en ontwikkelingsmoontlikhede

- tevredenheid met werk in die algemeen

\section{METODE}

Daar is van 'n ex post facto veldstudie met ' $n$ korrelasionele ontwerp gebruik gemaak. 'n Enkele groep proefpersone in die kleinhandel is eenmalig gemeet ten opsigte van twee veranderlikes, naamlik werknemerstatus (voltyds of tydelik) en werkhouding (in hierdie geval werktevredenheid). Die metings ten opsigte van hierdie veranderlikes is ontleed om te bepaal of die voltydse en deeltydse proefpersone verskil ten opsigte van hul werktevredenheid, en om sodoende te bepaal of daar 'n verband bestaan tussen werknemerstatus en werkhouding.

Die volgende hipoteses word gestel:

Ha 1: Daar sal 'n beduidende verskil wees tussen voltydse en deeltydse werkers ten opsigte van tevredenheid met hul werk in die algemeen

Ha 2: Daar sal 'n beduidende verskil wees tussen voltydse en deeltydse werkers ten opsigte van tevredenheid met besoldiging

Ha 3: Daar sal ' $n$ beduidende verskil wees tussen voltydse en deeltydse werkers ten opsigte van tevredenheid met werksekuriteit

Ha 4: Daar sal ' $n$ beduidende verskil wees tussen voltydse en deeltydse werkers ten opsigte van tevredenheid met sosiale aspekte in die werksituasie

Ha 5: Daar sal' $n$ beduidende verskil wees tussen voltydse en deeltydse werkers ten opsigte van tevredenheid met toesighouding

Ha 6: Daar sal ' $n$ beduidende verskil wees tussen voltydse en deeltydse werkers ten opsigte van tevredenheid met groei- en ontwikkelingsmoontlikhede

Ha 7: Daar sal ' $n$ beduidende verskil wees tussen voltydse en deeltydse werkers ten opsigte van werktevredenheid as geheel (gemiddeld van die gemiddeldes vir die afsonderlike aspekte van werktevredenheid)

Steekproef

Daar is besluit om die kleinhandel as teikenpopulasie vir hierdie studie te kies, waar benewens vir'n permanente kernkorps van voltydse werknemers, swaar op deeltydse werknemers gesteun word om organisasiedoelwitte te bereik. Ten einde steuringsveranderlikes te beheer wat werkerhoudings kan beïnvloed, soos die aard van werk, toesighouers en organisasiekultuur is proefpersone uit ' $n$ enkele winkelgroep by ' $n$ bepaalde tak geselekteer om aan die studie deel te neem. Slegs proefpersone wat ongeveer ' $n$ jaar of langer by die winkel werksaam is en deeglike blootstelling gehad het aan die organisasiekultuur, die toesighouers, omstandighede by die winkel en die aard van die werk is geselekteer. Voltydse en deeltydse werknemers is op grond van beskikbaarheid in die ondersoek betrek. Die populasie waaruit die steekproef geneem sou word, bestaan uit 'n verskeidenheid bevolkings- en taalgroepe waarvan die meerderheid laaggeskoolde swartmense is. Omrede dit vir die navorser nie moontlik was om van 'n meer geskikte responsinsamelingsmetode soos semi-gestruktureerde onderhoude gebruik te maak nie vanweë praktiese omstandighede, is besluit om van vraelyste gebruik te maak.

\section{Meetinstrumente}

'n Aantal vraelyste is oorweeg om in hierdie studie gebruik te word om werktevredenheid te meet:

- "An Index of Job Satisfaction" (Brayfield \& Rothe, 1951), soos gebruik deur Jackofsky en Peters (1987).

- "Job Descriptive Index" (JDI) (Smith, Kendall \& Hulin, 1969), soos gebruik deur Jackofsky en Peters (1987).

- "Job Diagnostic Survey" (JDS) (Hackman \& Oldham, 1974) soos gebruik deur Feldman en Doerpinghaus (1992b).

Wat eerstens die keuse van 'n meetinstrument beïnvloed, is die teorie waarop werktevredenheid as konstruk gebaseer is. Daar word kortliks aandag gegee aan twee basiese ontwikkelingslyne in die teorie van werktevredenheid. Brayfield en Rothe (1951:307) het beklemtoon dat 'n meetinstrument om werktevredenheid te meet "should give an index to 'over-all' job satisfaction rather than to specific aspects of the job situation". Volgens Coster (1992) is daar 'n aansienlike hoeveelheid literatuur wat 'n positiewe verband tussen werkervaring en algemene werktevredenheid rapporteer.

In teenstelling met die teorie van werktevredenheid as ' $n$ konstruk gebaseer op oorkoepelende, algemene werktevredenheid, is daar ook die teorie van werktevredenheid as 'n meerdimensionele, komplekse konstruk gebaseer op die verskillende basiese dimensies waaruit 'n werk bestaan (Coster, 1992; Locke, 1976; Smith et al., 1969; Van Vuuren, 1993). Coster (1992) het aangetoon dat die meting van spesifieke werkfasette om die som van die algehele tevredenheid met 'n werk te bepaal, ' $n$ beter maatstaf is as om slegs oorkoepelende, algemene werktevredenheid te meet. Die werktevredenheidskale van die "Job Diagnostic Survey" of JDS, en dif "Job Descriptive Index" of JDI, is gebaseer op die teorie van werktevredenheid as 'n meerdimensionele konstruk, aangesien dit spesifieke werktevredenheidfasette meet. Die JDSwerktevredenheidskale meet spesifieke werktevredenheidfasette sowel as algemene werktevredenheid. Brayfield en Rothe (1951) se "An Index of Job Satisfaction" meet slegs algemene werktevredenheid.

Die JDI meet werktevredenheid deur middel van lyste adjektiewe en kort frases. Volgens Smith et al. (1969) vereis die JDI nie dat die respondent in staat moet wees om te abstraheer of lang, vae sinne met verskeie kwalifiserings te verstaan nie. Dit vereis slegs dat die algemene betekenis van enkele woorde of kort frases verstaan word. Die JDS daarenteen, maak van Likertskale gebruik.

'n Verdere faktor wat by die keuse van 'n meetinstrument in ag geneem moes word, was dat dit eenvoudig moes wees om gebruik te kon word vir laag geskoolde persone uit verskillende taalgroepe, kultuur- en sosio-ekonomiese agtergronde.

Teen hierdie agtergrond is besluit om 'n loodsstudie uit te voer onder lede van 'n populasie soortgelyk aan die populasie waaruit beoog is om 'n steekproef vir hierdie studie te neem, om te bepaal watter van die JDS-werktevredenheidskale of die JDI die geskikste sou wees om in hierdie studie te gebruik. Die kwalifikasies van die tien deelnemers het gewissel tussen 
standerd agt en gediplomeerd. Die huistale was Noord-Sotho, Afrikaans, Engels, Duits en Zoeloe.

Die loodsstudie het getoon dat respondente meer moeite gehad het om die lyste adjektiewe van die JDI te verstaan en toe te pas, as wat die geval was met die JDS-werktevredenheidskale. Die "cannot decide/kan nie besluit nie"-opsic is 98 keer gebruik by die JDI, teenoor 19 response van dieselfde opsie by die JDS. Vier onbeantwoorde items by die JDI het voorgekom, teenoor geen onbeantwoorde items by die JDS. Uit onderhoude met drie van die respondente na die uitvoering van die loodsstudie het dit geblyk dat die respondente die betekenisse van sommige van die adjektiewe nie geken het nie. Smith et al. (1969) se argument dat kandidate nie nodig het om lang, vae sinne te abstraheer nie, en dat slegs algemene betekenisse van enkele woorde geken moet word, kan dus nie aanvaar word nie. Dit blyk dat betekenis deur anderstaliges in die loodsstudie makliker afgelei is uit sinne in plaas van ' $n$ enkele woord. Dit het geblyk dat die "cannot decide/kan nie besluit nie"-opsie eerder ' $n$ gebrek aan woordeskatkennis weerspieël as onsekerheid. Wat hierby aansluit, is die feit dat die respondente dikwels gevoel het dat net 'n "yes/ja", of net 'n "no/nee" of net 'n "cannot decide/kan nie besluit nie", nie volkome waar is nie. Hierteenoor bied die JDS sewe alternatiewe. Die respondent het dus 'n wyer keuse van alternatiewe, wat sy/haar persepsie akkurater kan weerspieël. Op grond van die voorafgaande is besluit om die werktevredenheiskake van die verkorte weergawe van die JDS te gebruik om werktevredenheid vir die doel van hierdie studie te meet.

Geldigheid en betroubaarheid van die "Job Diagnostic Survey"

Hackman en Oldham (1974) meld dat die JDS drie siklusse van voortoetsing en hersiening ondergaan het. In die proses is dit afgeneem op meer as 1500 werknemers in meer as 100 verskillende beroepe in verskillende organisasies. Volgens Hackman en Oldham (1974) toon die ontledings oor die algemeen dat die instrument oor voldoende konstrukgeldigheid beskik, en dat die diskriminasiewaardes van die items bevredigend is.

Wotruba (1990) het 'n studie aangaande die verskil in werktevredenheid tussen voltydse en deeltydse verkoopspersoneel 10 items van die werktevredenheidskale van die JDS gebruik. Die Cronbach alfakoëffisiënt in dié studie was 0.95 . Wotruba (1990) verwys verder ook na verskeie ander studies wat gedoen is waarin die werktevredenheidskale van die JDS suksesvol as meetinstrument gebruik is om werktevredenheid in handelsorganisasies te meet. Feldman en Doerpinghaus (1992b) het ook die JDS gebruik, en rapporteer 'n alfakoëffisiënt van 0.73 . Die JDS beskik dus oor voldoende geldigheid en betroubaarheid.

\section{Prosedure}

$\mathrm{Na}$ oorlegpleging met die menslike hulpbronbestuurder by die tak van die winkelgroep waar die navorsingsgegewens ingesamel sou word, is besluit cin die volgende prosedure te volg: die proefpersone wat bereid was om aan die studie deel te neem, het die vraelyste in groepies van ongeveer tien as deel van normale opleidingsessies onder leiding van die menslike hulpbronbestuurder voltooi. Die vraelyste is individueel voltooi, maar probleme in verband met die interpretasie van items is in groepsverband bespreek en deur die menslike hulpbronbestuurder opgeklaar. Daar is sover moontlik gepoog om 'n eenvormige prosedure met elke groep te volg. Op hierdie wyse is gepoog om probleme met die voltooing van die vraelyste wat sou ontstaan as gevolg van die lae geskooldheidsvlak van die werkers, asook die kommunikasieprobleem as gevolg van die verskeidenheid moedertale, te hanteer.

Die menslike hulpbronbestuurder het die probleem van responsingesteldheid van sosiale wenslikheid sover moontlik probeer beperk deur die inhoud van die begeleidende brief van die skrywer aan die respondente te beklemtoon.

Die rede waarom hierdie prosedure gevolg is waar die vraelyste in groepsverband deurgewerk en individueel voltooi is, was dat vorige pogings waar selfvoltooiigsvraelyste aan werkers uitgedeel is om dit self individucel op hul cie te voltooi, nie suksesvol verloop het nie. Hierdie prosedure bring egter ' $n$ bepaalde tekortkoming vir die studie mee: die response van die deelnemers wat die vraelyste in groepverband voltooi het, kon deur verskeie faktore beinvloed word, byvoorbeeld groepsdinamika, unicke gebeurtenisse, moontlike wisselvallige optrede deur die menslike hulpbronbestuurder, ensovoorts. Hierdie proses, asook die feit dat die steekproef gebaseer is op beskikbaarheid in stede van ewekansigheid, hou bepaalde implikasies in vir die interpretasie van die navorsingsresultate, wat vervolgens uiteengesit sal word.

\section{Verwerking van gegewens}

Die response wat deur middel van die vraelyste ingesamel is, is statisties verwerk met behulp van die SAS-rekenaarprogram (SAS Institute, 1988). Om die beduidendheid van verskille tussen die gemiddeldes van veranderlikes te bepaal, is gebruik gemaak van t-toetse vir onafhanklike gegewens. Resultate is as statisties betekenisvol beskou as die waarskynlikheidswaardes kleiner of gelyk aan vyf present is.

Deelname aan die studie was vrywillig. Die proefpersone is geselekteer op grond van beskikbaarheid, en die steekproef is daarom nie ewekansig nie. Om hierdie rede is daar by veranderlikes waar wel statisties beduidende verskille tussen permanent-voltydse en deeltydse werknemers aangetoon is, ook 'n effekgrootte (d-waarde) bereken om die grootte van die statistiese beduidendheid aan te toon. 'n Beduidende verskil met ' $n$ effekgrootte van groter as $0,8(d \geq 0,8)$ is vanweë die tekortkoming van nie-ewekansigheid as kriterium gebruik om te bepaal of ' $n$ verskil tussen die twee groepe groot genoeg is om gevolgtrekkings te maak aangaande die spesifieke doelstelling van hierdie studie. Hierdie proses om die effekgrootte van statisties beduidende verskille te bereken, word beskryf deur Cohen (1988).

\section{RESULTATE}

TABEL 1

BEDUIDENDHEID VAN DIE VERSKILLE TUSSEN DIE VOLTYDSE EN DEELTYDSE PROEFPERSONE TEN OPSIGTE VAN WERKTEVREDENHEID

\begin{tabular}{|c|c|c|c|c|c|}
\hline Veranderlike & Groep & $x$ & $\mathrm{~s}$ & p & $\mathrm{d}$ \\
\hline \multirow{2}{*}{$\begin{array}{l}\text { Algemene } \\
\text { werktevredenheid }\end{array}$} & Voltyds & 5,13 & 1,53 & 0,3700 & - \\
\hline & Deeltyds & 4,83 & 1,72 & & \\
\hline \multirow{2}{*}{$\begin{array}{l}\text { Tevredenheid met } \\
\text { besoldiging }\end{array}$} & Voltyds & 3,74 & 1,85 & ${ }^{*} 0,0037$ & 0,5 \\
\hline & Deeltyds & 2,77 & 1,40 & & \\
\hline \multirow{2}{*}{$\begin{array}{l}\text { Tevredenheid met } \\
\text { werksekuriteit }\end{array}$} & Voltyds & 4,32 & 1,51 & ${ }^{*} 0,0023$ & 0,5 \\
\hline & Deeltyds & 3,43 & 1,36 & & \\
\hline \multirow{2}{*}{$\begin{array}{l}\text { Tevredenheid met } \\
\text { sosiale aspekte }\end{array}$} & Voltyds & 5,50 & 1,11 & ${ }^{*} 0,0042$ & 0,5 \\
\hline & Deeltyds & 4,71 & 1,50 & & \\
\hline \multirow{2}{*}{$\begin{array}{l}\text { Tevredenheid met } \\
\text { toesighouding }\end{array}$} & Voltyds & 4,67 & 1,46 & ${ }^{*} 0,0001$ & 1,08 \\
\hline & Deeltyds & 3,09 & 1,32 & & \\
\hline \multirow{2}{*}{$\begin{array}{l}\text { Tevredenheid met } \\
\text { groei- en ontwikkelings- } \\
\text { moontlikhede }\end{array}$} & Voltyds & 4,71 & 1,30 & 0,0612 & - \\
\hline & Deeltyds & 4,19 & 1,47 & & \\
\hline \multirow{2}{*}{$\begin{array}{l}\text { Verskil tussen groepe } \\
\text { ten opsigte van werk- } \\
\text { tevredenheid as geheel }\end{array}$} & Voltyds & 4,89 & 0,85 & ${ }^{*} 0,0003$ & 0,7 \\
\hline & Deeltyds & 4,23 & 0,90 & & \\
\hline
\end{tabular}


In tabel 1 word die verskille aangetoon tussen die voltydse en deeltydse proefpersone ten opsigte van werktevredenheid. Ten opsigte van die afsonderlike fasette van werktevredenheid blyk dit dat die twee groepe betekenisvol verskil ten opsigte van:

* tevredenheid met besodiging, $p=0,0037, d=0,5$, (medium effekgrootte)

* tevredeheied met werksekuriteit, $p=0,0023, d=0,5$, (medium effekgrootte)

- tevredenheid met sosiale aspekte, $p=0,0042, d=0,5$, (medium effekgrootte)

* tevredenheid met toesighouding, $p=0,0001, d=1,08$, (groot effekgrootte)

Omrede die steekproef nie ewekansig is nie, kan tot die gevolgtrekking gekom word dat die twee groepe in terme van statistiese beduidendheid en effekgrootte ten opsigte van een faset van werktevredenheid verskil, naamlik tevredenheid met toesighouding. Daar is nie statisties beduidende verskille ten opsigte van algemene werktevredenheid $(p=0,37)$ en tevredenheid met groei- of ontwikkelingsmoontikhede $(p=$ $0,06)$ nie, afgesien van effekgrootte.

Die twee groepe verskil beduidend ten opsigte van die saamgestelde werktevredenheid (gemiddeld van die gemiddeldes vir die afsonderlike werktevredenheidfasette), waar $p=$ 0,0003 , op die $5 \%$ beduidendheidspeil. Hierdie verskil moet omsigtig geinterpreteer word, aangesien die effekgtootte daarvan medium tot groot $(\mathrm{d}=0,7)$ is.

Samevattend word die alteratiewe hipoteses $\mathrm{Ha} 1, \mathrm{Ha} 2, \mathrm{Ha} 3$, $\mathrm{Ha} 4$, $\mathrm{Hab}$ en $\mathrm{Ha} 7$ verwerp. Die alternatiewe hipotese $\mathrm{Ha} 5$ word nie verwerp nie, aangesien die twee groepe statisties beduidend en ook ten opsigte van effekgrootte genoegsaam verskil.

\section{BESPREKING}

Die resultate van hierdie studie stem gedeeltelik ooreen met vorige navorsingsbevindinge, soos dié van Wakefield et al. (1987), Hom (1979), en Still (1983), en verskil met bevindinge soos dié van Logan et al. (1973), Eberhardt en Shani (1984), Wetzel et al. (1990), Miller en Terborg (1979), Jackofsky en Peters (1987) en Lee en Johnson (1991). Daar is reeds aangetoon dat daar baie veranderlikes is wat by elke studie ten opsigte van deeltydse en voltydse werkers verskil, wat meebring dat navorsingsbevindinge nie sonder voorbehoud vergelyk en veralgemeen kan word nie.

Die deeltydse werkers se vlak van werktevredenheid is beduidend laer as dié van die voltydse werkers ten opsigte van slegs een faset, naamlik tevredenheid met toesighouding.

Alhoewel die deeltydse werkers se werktevredenheid ten opsigte van besoldiging, werksekuriteit en sosiale aspekte in terme van statistiese beduidenheid laer is as as die van die voltydse werkers, is die effekgrootte van hierdie verskille nie groot genoeg nie. Daar was geen statisties beduidende verskil tussen die twee groepe ten opsigte van algemene werktevredenheid en tevredenheid met groei-en ontwikkelingsmoontlikhede nie.

Die saamgestelde werktevredenheid vir die twee groepe (gemiddeld van die gemiddeldes vir al die werktevredenheidfasette) verskil statisties beduidend, en kom naby daaraan om in terme van effekgrootte genoegsaam te verskil, aangesien die d-waarde 0,7 is. Dit is in kontras met die response ten opsigte van algemene werktevredenheid, waar die proefpersone moes aandui hoe hulle oor die algemeen oor hulle werk voel, en die twee groepe ten opsigte van hierdie faset nie statistics beduidend verskil nie. Hierdie resultaat ondersteun die bevinding van Coster (1992) dat die meting van spesifieke werkfasette om die som van die algehele werktevredenheid met ' $n$ werk te bepaal, ' $n$ beter maatstaf is as om slegs oorkoepelende, algemene werktevredenheid te meet.

Met inagneming van die lewensomstandighede van die deeltysde werkers, sou mens verwag dat die grootste beduidende verskil tussen die twee groepe ten opsigte van tevredenheid met werksekuriteit sou wees. Tog is dit eerder ten opsigte van tevredenheid met toesighouding waar die twee groepe beduidend verskil. Dit dui daarop dat toesighouding as 'n ekstrinsieke werkfaktor ' $n$ belangrike impak het op die werktevredenheid van die deeltydse werkers wat betref die strukturele werktoestande waarbinne hulle werk.

Hierdie resultaat ten opsigte van toesighouding het belangrike implikasies. Die bevinding dui daarop dat daar 'n probleem kan wees wat betref die uitsette wat toesighouers lewer in die bestuur van hierdie deeltydse werkers. Dit sluit aan by die bevinding van Nkomo en Fields (1994) wat 'n studie uitgevoer het met die doel om die verband te bepaal tussen demografiese eienskappe en persepsies van belangrike werkeienskappe onder deeltydse werkers by ' $n$ kettingwinkelgroep. Die belangrikste aspek wat deur al die demografiese klassifikasies in die steekproef uitgewys is ten opsigte van werkeienskapvoorkeure, was dié van " $n$ toesighouer met wie ek kan saamwerk". Shockey en Mueller (1994) het bevind dat deeltydse en voltydse werkers nie verskil wat betref werkonëntasies en verwagtings wanneer die werkervaring ' $n$ aanvang neem nie, Dit is die werklike behandeling (strukturele werksomstandighede) wat werkers ervaar wat verskillende reaksies tussen die werknemerstatusgroepe teweeg bring. Hulle wys daarop dat dit moontlik is dat deeltydse werkers behandel word asot hulle minder gemotiveerd, minder tevrede en minder verbind tot hul werk sal wees wat' $n$ selfvervullende profesie skep. Volgens Miller en Terborg (1979) het toesighouers dikwels die persepsie aangaande deeltydse werkers dat hulle aangestel word om minder aangename take te doen en onafgehandelde werk van voltydse workers te voltooi. Die motivering vir Still (1983) se studie was dat daar oor die algemeen ' $n$ negatiewe persepsie by bestuur bestaan dat deeltydse werkers minder verbind is tot hul organisasie, hul departement of afdeling en hul werk in vergelyking met voltydse werkers. Zeytinoglu (1992) se navorsing bevestig dat werkgewers ' $n$ onderskeid mak wat betref voltydse en deeltydse werkers en die mate van werkverbintenis, doeltreffendheid en personeelomset wat by hierdie groepe oor die algemeen aangetref word. Werkgewers se persepsie van deeltydse werkers is dat hulle beskou moet word as ' $n$ aparte groep met die laagste werkverbintenis en doeltreffendheid, en die hoogste personeelomset van al die werknemerstatusgroepe. Dit is moontlik dat hierdie algemene, ongunstige werkgewerpersepsies ook by die toesighouers van die proefpersone in hierdie studie manifesteer, en dat dit moontlik verklaar waarom die deeltydse werkers in hierdie studie so beduidend verskil van die voltydse werkers wat betref tevredenheid met toesighouding.

Wat verder hierby aansluit, is dat laevlak deeltydse werkers wat hoogsgestruktureerde werk doen, waarskynlik ondersteunende of rigtinggewende toesighouding benodig (Darden et al., 1993; Nkomo \& Fields, 1994; Wakefield et al., 1987). Die proefpersone in hierdie studie is waarskynlik om dieselfde rede sterk aangewese op hul toesighouers, daarom mak die toesighouding 'n groot verskil aan hul werktevredenheid.

Toesighoueropleiding is ' $n$ belangrike aspek wat prominente aandag behoort te geniet. Nkomo en Fields (1994:374) het na aanleiding van hul bevinding met betrekking tot die belangrikheid van toesighoueropleiding die opmerking gemaak dat "companies cannot afford to wait on the results of 'on-the-job' training as newly appointed supervisors develop their management skills on a trial and error basis". Opleidingsprogramme wat ook fokus op die ontwikkeling van fasiliteringsvaardighede, is nodig wat toesighouers in staat sal stel om spanleiers te word wat sal weet hoe om ' $n$ balans te handhaaf tussen werknemerbehoeftes (werknemermoraal en -tevredenheid) en organisasiedoelwitte (afhandeling van die werk, kliëntesorg). So 'n benadering hang egter ook ten nouste saam met aspekte soos die organisasiekultuur, personeelbeleid en korporatiewe doelwitte. 
Samevattend kan tot die gevolgtrekking gekom word dat daar wel' $n$ verskil is tussen die voltydse en deeltydse werkers in die steekproef, ten opsigte van een aspek van werktevredenheid, naamlik tevredenheid met toesighouding.

Wat die algemene doelstelling van hierdie studie betref, blyk dit dat daar wel ' $n$ verband tussen werknemerstatus en werkverwante houdings kan bestaan.

Wat tekortkominge betref, word die veralgemeenbaarheid van die navorsingsbevindinge beperk deurdat die navorsing by ' $n$ enkele tak van ' $n$ bepaalde winkelgroep gedoen is. Die voordeel hiervan is dat steuringsveranderlikes beter beheer word. Die steekproef waarop die studie berus, is klein ( $n=$ 101). Omstandighede het meegebring dat ' $n$ groter steekproef nie verkry kon word nie - deelname was vrywillig. Verder moes die vraelyste voltooi word tydens opleidingsessies onder leiding van die menslike hulpbronbestuurder van die winkeltak binne werkure, terwyl die deeltydse werkers juis minder dae werk as die voltydse werkers.

Hierdie omstandighede het meegebring dat die studie nie op 'n ewekansige steekproef berus nie, maar op beskikbaarheid van proefpersone om aan die studie deel te neem. Die veralgemeenbaarheid van die navorsingsresultate, asook die betroubaarheid en geldigheid van die navorsing, word as gevolg hiervan beperk.

'n Opvolgstudie word aanbeveel waar'n groter steekproef, wat berus op ewekansigheid, gebruik word.

Vanweë die probleme wat ondervind is met die voltooüng van die vraelyste deur die laaggeskoolde proefpersone en die spesiale reëlings wat as gevolg daarvan getref moes word, word aanbeveel dat met ' $n$ opvolgstudie semi-gestruktureerde onderhoude met individuele proefpersone gevoer word om response in te samel. Opgeleide veldwerkers, wat in die moedertaal van die proefpersone kan kommunikeer, sal die betroubaarheid en geldigheid van die response verhoog.

'n Opvolgstudie word aanbeveel waar die steekproef die werkers van ander takke binne dieselfde winkelgroep insluit. Dit sal meebring dat verskillende werknemerstatusgroepe nie net binne ' $n$ enkele tak van ' $n$ organisasie vergelyk word nie, maar ook tussen verskillende takke ten opsigte van verskeie veranderlikes, wat gedrag soos werkprestasie, kan insluit.

\section{VERWYSINGS}

Backer, L. (1996, Februarie 8). Die makelaars spaar ondernemings geld. Rapport, p. 18

Bravfield. A.H. \& Rothe, H.F. (1951). An Index of Job Satisfaction, Journal of Applied Psychology, 35(5), 307-311.

Casey, B. (1988). Temporary Employment: practice and policy in Britain. London: Policy Studies Institute

Cohen, J. (1988). Statistical Power Analysis for the Behavioral Sciences. 2nd ed. Hillsdale, N.J.: Lawrence Er!baum.

Coster, E.A. (1992). The perceived quality of working life and job facet satisfaction. Joumal of Industrial Psychology, 18(2), 6-9.

Darden, W.R., McKee, D. \& Hampton, R. (1993). Salesperson Employment Status as a Moderator in the Job Satisfaction Model A Frame of Reference Perspective. Journal of Personal Selling \& Sales Management, 13(3), 1-15.

Dederichs, E. \& Köhler, E. (1993). Part-time Work in the European Community: the economic and social dimension. Dublin: European Foundation for the improvement of living and working conditions.

Eberhardt, B.J. \& Moser, S.B. (1995). The nature and consequences of part-time work: a test of hypotheses. Joumal of Applied Business Research, 11(3), 101-108.

Eberhardt, B.J. \& Shani, A.B. (1984). The effects of full-time versus part-time employment status on attitudes toward specific organizational characteristics and overall job satisfaction. Academy of Management Joumal, 27(4), 893-900.

Feldman, D.C (1990). Reconceptualizing the nature and consequences of part-time work. Academy of Managenent Review, 15(1), 103-112.

Feldman, D.C. \& Doerpinghaus, H.I. (1992a). Missing persons no longer: Managing part-time workers in the "90s. Organizational Dynamics, 21, 59-72.

Feldman, D.C. \& Doerpinghaus, H.I. (1992b). Patterns of parttime employment. Joumal of Vocational Behavior, 41, 282 294.

Feldman, D.C, Doerpinghaus, H.I. \& Turnley, W.H. (1995). Employee reactions to temporary jobs. Joumal of Managerial Issues, 7(2), 127-141.

Fields, M.W. \& Thacker, J.W. (1991). Job-related attitudes of part-time and full-time workers. Joumal of Managerial Psychology, 6(2): 17-20.

Hackman, J.R \& Oldham, G.R. (1974). The job Diagnostic Survey: An instrument for the diagnosis of jobs and the evaluation of job redesign projects. New Haven, Connecticut: Yale University.

Hall, D.T. \& Gordon, F.E. (1973). Career choices of married women: effects on conflict, role behavior and satisfaction. Journal of Applied Psychology, 58(1), 42-48.

Hom, P.W. (1979). Effects of job peripheralty and personal characteristics on the job satisfaction of part-time workers. Academy of Management joumal, 22(3), 551-565.

Houseman, S.N. (1995). Part-time employment in Europe and Japan. Journal of Labor Research, 16(3), 249-262.

Jackofsky, E.F. \& Peters, L.H. (1987). Part-time versus full-time employment status differences: a replication and extension. Joumal of Occupational Behaviour, 8, 1-9.

Klerck, G. (1991) Casualisation and sub-contracting employer weapons against unions. South African Labour Bulletin. 15(7), 44-47.

Lee, T.W. \& Johnson, D.R. (1991). The Effects of Works Schedule and Employment Status on the Organizational Commitment and Job Satisfaction of Full versus Part Time Employees. Joumal of Vocational Behavior, 38(2), 208-224.

Levy, A. \& Associates. (1995). The 'non-permanent' employee: a permanent problem? How to handle temps, casuals and probationers. Johannesburg: Andrew Levy \& Associates.

Levy, A. \& Associates. (1996). The New Basic Conditions of Employment Act. Johannesburg: Andrew Levy \& Associates.

Lewis, W. \& Schuman, N. (1988). The temp worker's handbook: how to make temporary employment work for you. New York: AMACOM.

Locke, E.A. (1976). The nature and causes of job satisfaction. In M.D. Dunnette (Ed.), Handbook of Industrial and Organizational Psychology (pp, 1297-1349). Chicago: Rand MeNally.

Logan, N., O'Reilly, C \& Roberts, K.H. (1973). Job satisfaction among part-time and full-time employees. Joumal of Vocational Behavior, 3, 33-41.

Mcrae, S. (1989). Flexible working fime and family life: a review of changes. London: Policy Studies Institute.

Miller, H.E. \& Terborg, J.R. (1979). Job attitudes of part-time and full-time employees. Journal of Applied Psychology, 64(4), 380-386.

Moberley, R.B. (1987). Temporary, part-time and atypical employment relationships in the USA. Labor Law Joumal 37, 689-696.

Nkomo, S.M. \& Fields, D.M. (1994). A field study of demographic characteristics and job attribute preferences of new part-time employees. Joumal of Business and Psychology, 8(3), 365-375.

Peters, L.H., Jackofsky, E.F. \& Salter, J.R. (1981). Predicting tumover: a comparison of part-time and full-time employees. Journal of Occupational Behaviour, 2, 89-98.

Prinsloo, F.G. (1997). Die verband tussen werknemerstatus en werkhoudings in ' $n$ kleinhandelgroep. Ongepubliseerde M.A. verhandeling, Potchefstroomse Universiteit vir Christelike Hoèr Onderwys, Potchefstroom.

Robinson, O. (1993), Employment in services: Perspectives on part-time employment growth in North America. Service Industries Journal, 13(3), 1-18.

Rotchford, N.L. \& Roberts, K.H. (1982). Part-time workers as missing persons in organizational research. Academy of Management Review , 7, 228-234. 
Sander, H. (1989). Voorbeelde van nie-tradisionele werkspatrone in die biblioteek- en inligtingwese: vryskutwerk en konsultasie. Suid-Afrikaanse tydskrif vir biblioteek-en inligtingkunde, 57(3):322-327.

SAS Institute. (1988). SAS user's guide: basics. 5th ed. Cary, N.C.: SAS Institute Inc.

Shockey, M.L. \& Mueller, C.W. (1994). At-entry differences in part-time and full-time employees. Journal of Business and Psychology, 8(3), 355-364.

Smith, P.C., Kendall, L.M. \& Hulin, C.L. (1969). The measurement of satisfaction in work and retirement.. Chicago: Randy McNally.

Soumerai, S.B \& Avorn, J. (1983). Perceived health, life satisfaction, and activity in urban elderly: a controlled study of the impact of part-time work. Journal of Gerontology, 38, 356-362.

Still, L.V. (1983). Part-time versus full-time salespeople: individual attributes, organizational commitment, and work attitudes. Journal of Retailing, s9(2), 55-79.

Syrett, M. (1983). Employing job snarers part-time and temporary staff. London: Institute of Pesonnel Management.
Van Vuuren, S.M \& Schepers, J.M. (1993). Die konstruksie en evaluering van 'n werkstevredenheidvraelys vir predikante. Tydskrif vir Bedryfsielkunde, 19(1), 23-27.

Volodia, I. (1991). Increase in casual and temporary labour: the case of shopworkers. South African Labour Bulletin, 15(7), 48-50.

Wakefield, D.S. Curry, J.P. Mueller, C.W. \& Price, J.L. (1987). Differences in the importance of work outcomes between full-time and part-time hospital employees. Journal of Occupational Behaviour, 8, 25-35.

Wetzel, K., Soloshy, D.E. \& Gallagher, D.G. (1990). The work attitudes of full-time and part-time registered nurses. Health Care Management Review, 15, 79-85.

Wotruba, T.R. (1990). Full-time vs. part-time salespeople: a comparison on job satisfaction, performance, and turnover in direct selling. International Journal of Research in Marketing, 7(2), 97-108.

Zeytinoglu, I.U. (1992). Unionized part-time professionals and opportunities for filling full-time vacancies and training. Industrial Relations - Quebec, 47(1), 59-78. 